\title{
Carriage of plasmid-mediated $q n r$ determinants and quinolone efflux pump (qepA) by ciprofloxacin-resistant bacteria recovered from Urinary Tract Infection (UTI) samples
}

\author{
Abimbola Olumide Adekanmbi ${ }^{1,2^{*}} \mathbb{C}$, Sandra Usidamen ${ }^{2,3}$, Olabisi Comfort Akinlabi ${ }^{4^{*}}$, \\ Adedolapo Victoria Olaposi ${ }^{1,2}$ and Anthony Abiodun Onilude ${ }^{5}$
}

\begin{abstract}
Background: Bacterial resistance to commonly-used antibiotics has been on the increase especially in the clinical settings. This study focused on the detection of plasmid-mediated quinolone resistance (PMQR) determinants in ciprofloxacin-resistant bacteria recovered from Urinary Tract Infection (UTI) samples.

Results: Already characterized isolates from urine samples of UTI-diagnosed in- and out- patients were obtained from the culture pool of the Department of Medical Microbiology and Parasitology, University College Hospital $(\mathrm{UCH})$, Ibadan, Nigeria. A total of seventy-three ciprofloxacin-resistant isolates were used in this study. Of the 73 UTI isolates, 43 carried at least one of the four PMQR genes targeted and they belonged to eight bacterial genera namely: Escherichia (25), Klebsiella (10), Pseudomonas (2), Proteus (2) and one isolate each belonging to Enterobacter, Acinetobacter, Citrobacter and Salmonella genera. qnrA was detected in 10.9\% (8/73) of the isolates while the occurrence of qnrB and qnrs was 32.9\% (24/73) and 20.5\% (15/73), respectively. The quinolone efflux pump (qepA) was detected in $9 / 73$ (12.3\%) of the isolates. Thirty of the isolates carried only one PMQR gene, while thirteen carried two PMQR genes. There was no carriage of more than two PMQR genes in the forty-three isolates from which PMQR genes were detected.

Conclusion: This study reports the carriage of PMQR determinants by eight of the nine Gram-negative bacterial genera from urinary sources in patients attending the University College Hospital, Ibadan over the four-month period of study. This is quite worrisome as it suggests a high contribution of UTI cases to the burden of quinolone resistance. There is a need for more studies of this nature in other hospitals in Nigeria, to develop a database on the contribution of UTI cases to quinolone resistance.
\end{abstract}

Keywords: Quinolone resistance, Urinary Tract Infection (UTI), Antibiotic resistance, PMQR genes, Tertiary Hospital

\section{Background}

\footnotetext{
*Correspondence: bimboleen@yahoo.com; ao.adekanmbi@ui.edu.ng akinlabi.olabisi@yahoo.com

${ }^{1}$ Environmental Microbiology and Biotechnology Laboratory, Department of Microbiology, University of Ibadan, Ibadan, Nigeria ${ }^{4}$ Department of Pharmaceutical Microbiology, Faculty of Pharmacy, University of Ibadan, Ibadan, Nigeria

Full list of author information is available at the end of the article
}

Urinary tract infections (UTIs) are one of the most common group of bacterial infections worldwide. It is estimated that the proportion of UTIs remains at a high level reaching 150 million episodes per year worldwide and accounting for an estimated $\$ 6$ billion in health care expenditures (Foxman 2014; AUA 2016). Resistance to beta-lactam antibiotics and fluoroquinolones, which are the most widely used therapeutics against UTI has 
skyrocketed lately (Grabe et al. 2015). The past 30 years have led to an explosive increase in quinolone resistance, especially among the Enterobacterales. This has been brought about by the acquisition of plasmid-mediated quinolone resistance genes (Briales et al. 2012; Alikhani et al. 2013).

Quinolone antibiotics have shown high effectiveness in the treatment of UTIs and other diseases as a result of their broad spectrum of activity, good oral absorption and unnoticeable side effects, making them the drug of choice in the treatment of a variety of infections (Mandell 2005; Shahcheraghi et al. 2013). The mechanisms used by bacteria to resist quinolones include alteration in the genes encoding quinolone target enzymes, regulation of proteins responsible for overexpression of quinolone efflux pumps and intake system (Hooper and Jacoby 2015); in addition to the possession of plasmid-mediated quinolone resistance (PMQR) determinants (Strahilevitz et al. 2009).

The first plasmid-mediated resistance gene in quinolones; qnrA1 was reported in 1998 from a clinical strain of Klebsiella pneumoniae and ever since then, more plasmids-transferable resistance mechanisms to quinolones have been identified (Poirel et al. 2005; Jacoby et al. 2008; Hernández et al. 2011; Ade et al. 2014; Ohene et al. 2019). In addition to this, other elements such as efflux pumps (oqxAB and qepA), and the possession of aminoglycoside acetyltransferase $\left(a a c\left(6^{\prime}\right)-I b-c r\right)$ have been reported to contribute to the resistance of bacteria to the quinolone antibiotics (Jacoby 2005; Strahilevitz et al. 2009). Before the 2000s, studies carried out in Nigeria have shown reports of low-level resistance to the quinolones among isolates of clinical origin probably because of the low patronage of the drugs back then (Lamikanra et al. 2011), but currently, there have been increasing reports of quinolone resistance in Nigeria and other neighboring countries in West Africa (Aibinu et al. 2004, 2008; Ogbolu et al. 2011, 2016). In lieu of this fact, this study aimed to determine the prevalence of plasmid-mediated $q n r$ and qepA quinolone resistance genes among ciprofloxacin-resistant uropathogens obtained from the urine of patients attending a University Teaching hospital in Nigeria over a 4-month period.

\section{Methods}

\section{Bacteria used for the study}

This study was carried out in April, 2021, and the isolates used for this study were ciprofloxacin-resistant uropathogens isolated from urine samples of UTI- diagnosed population attending the University College Hospital, over a period of 4 months. The Teaching hospital is located
Table 1 Oligonucleotide primers and amplicon sizes of PMQR genes targeted in this study

\begin{tabular}{llll}
\hline Target gene & Primer sequence (5' to 3') & $\begin{array}{l}\text { Amplicon } \\
\text { size (bp) }\end{array}$ & References \\
\hline qnrA & TTCAGCAAGAGGATTTCTCA & 608 & Wu et al. (2007) \\
& GGCAGCACCATTACTCCCAA & & \\
qnrB & CCTGAGCGGCACTGAATT & 389 & Wu et al. (2007) \\
& CAT & & \\
& GTTTGCTGCTCGCCAGTCGA & & \\
qnrs & CAATCATACATATCGGCACC & 621 & Wu et al. (2007) \\
& TCAGGATAAACAACAATA & & \\
& CCC & & \\
qepA & GCAGGTCCAGCAGCGGGT & 218 & Wu et al. (2007) \\
& AG & & \\
& CTTCCTGCCCGAGTATC & & \\
& GTG &
\end{tabular}

Table 2 Frequency of ciprofloxacin-resistant bacterial genera and their carriage of PMQR genes

\begin{tabular}{llll}
\hline Bacteria & Frequency & $\begin{array}{l}\text { Percentage } \\
\text { occurrence }\end{array}$ & $\begin{array}{l}\text { No. of isolates showing } \\
\text { carriage of PMQR } \\
\text { genes }\end{array}$ \\
\hline Escherichia spp. & $31 / 73$ & 42.5 & 25 \\
Klebsiella spp. & $27 / 73$ & 36.9 & 10 \\
Pseudomonas spp. & $4 / 73$ & 5.5 & 2 \\
Enterobacter spp. & $3 / 73$ & 4.1 & 2 \\
Proteus spp. & $3 / 73$ & 4.1 & 1 \\
Acinetobacter spp. & $2 / 73$ & 2.7 & 1 \\
Citrobacter spp. & $1 / 73$ & 1.4 & 1 \\
Salmonella spp. & $1 / 73$ & 1.4 & 1 \\
Morganella spp. & $1 / 73$ & 1.4 & 0 \\
Total & 73 & 100 & 43 \\
\hline
\end{tabular}

in Ibadan, a city in the South-western part of Nigeria. The uropathogenic bacteria were obtained with written approval, from the culture collection of the Department of Microbiology and Parasitology, University College Hospital (UCH). The Microbact ${ }^{\mathrm{TM}}$ Gram Negative System Identification kit (Thermo Scientific-Oxoid, UK) was used in the identification of the uropathogenic bacteria.

\section{DNA extraction and PCR amplification of plasmid-mediated quinolone resistance (PMQR) genes} The genomic DNA of the seventy-three ciprofloxacinresistant bacteria was extracted using the boiling lysis method (Gugliandolo et al. 2010). The methods described by $\mathrm{Wu}$ et al. (2007) were used in the amplification of the targeted PMQR genes ( $q n r A, q n r B$, qnrS and qepA genes). The oligonucleotide primers and amplicon sizes of PMQR genes targeted in this study are highlighted in Table 1. 
Table 3 Distribution of anr determinants and qepA in the Urinary Tract Infection isolates showing the carriage of PMQR genes

\begin{tabular}{|c|c|c|c|c|c|}
\hline Lab code & Isolate identity & qnrA & $q n r B$ & qnrS & qepA \\
\hline UP1 & Escherichia coli & - & - & - & + \\
\hline UP2 & Escherichia coli & - & + & - & - \\
\hline UP3 & Escherichia coli & - & + & - & + \\
\hline UP4 & Enterobacter cloacae & - & - & + & + \\
\hline UP5 & Escherichia coli & - & + & - & + \\
\hline UP6 & Acinetobacter baumannii & - & + & - & - \\
\hline UP7 & Escherichia coli & - & + & - & - \\
\hline UP9 & Klebsiella pneumoniae & + & - & - & - \\
\hline UP10 & Escherichia coli & - & - & - & + \\
\hline UP13 & Klebsiella pneumoniae & - & - & + & - \\
\hline UP20 & Escherichia coli & - & - & + & - \\
\hline UP21 & Escherichia coli & - & - & + & - \\
\hline UP22 & Escherichia coli & - & + & - & - \\
\hline UP23 & Escherichia coli & - & + & - & - \\
\hline UP24 & Pseudomonas aeruginosa & - & + & + & - \\
\hline UP25 & Escherichia coli & - & + & - & - \\
\hline UP26 & Citrobacter amalonaticus & - & + & - & - \\
\hline UP27 & Escherichia coli & - & + & - & - \\
\hline UP28 & Escherichia coli & - & + & - & - \\
\hline UP29 & Klebsiella oxytoca & - & + & + & - \\
\hline UP36 & Escherichia coli & - & + & - & - \\
\hline UP38 & Klebsiella pneumoniae & - & - & + & - \\
\hline UP40 & Escherichia coli & - & - & + & - \\
\hline UP41 & Escherichia coli & + & - & - & - \\
\hline UP42 & Klebsiella pneumoniae & - & - & + & - \\
\hline UP43 & Pseudomonas aeruginosa & + & + & - & - \\
\hline UP44 & Escherichia coli & + & + & - & - \\
\hline UP45 & Klebsiella pneumoniae & - & + & + & - \\
\hline UP46 & Escherichia coli & - & + & - & + \\
\hline UP47 & Escherichia coli & - & + & - & + \\
\hline UP48 & Klebsiella pneumoniae & + & - & - & - \\
\hline UP50 & Klebsiella pneumoniae & - & + & - & - \\
\hline UP51 & Klebsiella pneumoniae & + & - & + & - \\
\hline UP53 & Salmonella enterica & - & - & + & - \\
\hline UP54 & Escherichia coli & - & - & + & - \\
\hline UP59 & Escherichia coli & - & - & + & - \\
\hline UP60 & Enterobacter cloacae & + & + & - & - \\
\hline UP61 & Escherichia coli & - & + & + & - \\
\hline UP62 & Klebsiella pneumoniae & - & + & - & - \\
\hline UP63 & Escherichia coli & - & - & - & + \\
\hline UP64 & Escherichia coli & - & - & - & + \\
\hline UP66 & Escherichia coli & + & - & - & - \\
\hline UP67 & Proteus mirabilis & - & + & - & - \\
\hline
\end{tabular}

\section{Results}

Thirty-one (42.5\%) of the ciprofloxacin-resistant bacteria were identified as Escherichia coli, while twenty-seven
(36.9\%) were Klebsiella spp., four (5.5\%) were Pseudomonas spp., while there were three isolates $(4.1 \%)$ each of Proteus spp. and Enterobacter spp. There were two Acinetobacter spp. isolates (2.7\%), with Citrobacter spp., Morganella spp. and Salmonella spp. having one isolate (1.4\%) each. Forty-three of the total isolates carried at least one of the targeted PMQR genes (Table 2).

The distribution of $P M Q R$ genes in the forty-three of the seventy-three UTI isolates showing the carriage of PMQR genes is shown in Table 3. Of the forty-three isolates showing the carriage of PMQR genes, 25 were Escherichia coli, 10 were Klebsiella spp., two each for Pseudomonas spp. and Proteus spp., while Enterobacter spp., Acinetobacter spp., Citrobacter spp. and Salmonella spp. had one isolate each. All the bacteria genera used in this study with the exception of the genus Morganella had at least one isolate showing the carriage of the targeted PMQR genes. The remaining thirty isolates did not carry any of the PMQR genes and were not presented in the Table.

Eight of the isolates representing $10.9 \%$ of the total 73 ciprofloxacin-resistant bacteria carried the qnrA gene,

Table 4 Frequency of occurrence of PMQR genes in the ciprofloxacin-resistant bacteria

\begin{tabular}{lll}
\hline PMQR gene & Frequency & $\begin{array}{l}\text { Percentage } \\
\text { occurrence } \\
\text { (\%) }\end{array}$ \\
\hline anrA & $8 / 73$ & 10.9 \\
anrB & $24 / 73$ & 32.9 \\
qnrS & $15 / 73$ & 20.5 \\
gepA & $9 / 73$ & 12.3 \\
\hline
\end{tabular}

Table 5 Carriage of different PMQR gene combination by the forty-three isolates carrying PMQR genes

\begin{tabular}{|c|c|}
\hline PMQR gene combinations & $\begin{array}{l}\text { Frequency } \\
\text { of } \\
\text { occurrence }\end{array}$ \\
\hline gnrA only & 4 \\
\hline qnrB only & 13 \\
\hline qnrs only & 9 \\
\hline gepA only & 4 \\
\hline$q n r A+q n r B$ & 3 \\
\hline$q n r A+q n r s$ & 1 \\
\hline$q n r B+q n r S$ & 4 \\
\hline$q n r A+q e p A$ & 0 \\
\hline$q n r B+q e p A$ & 4 \\
\hline$q n r s+q e p A$ & 1 \\
\hline$q n r A+q n r B+q n r S$ & 0 \\
\hline$q n r A+q n r B+q n r S+q e p A$ & 0 \\
\hline
\end{tabular}


which is the gene with the least frequency of occurrence among the uropathogenic isolates. qnrS was detected in fifteen isolates (20.5\%), with qepA being harboured by nine of the isolates $(12.3 \%)$. The predominant gene of the PMQR genes targeted in this study was qnrB, which was detected in 24/73 (32.9\%) of the isolates as shown in Table 4 . Thirty of the isolates carried only one of the PMQR genes targeted, while thirteen carried two of the four PMQR genes. There was no carriage of more than two PMQR genes in the forty-three isolates detected to harbour the genes.

Table 5 is showing the carriage of different PMQR gene combination by the forty-three from which PMQR genes were detected. Four isolates carried qnrA only, while thirteen, nine and four isolates, respectively, carried $q n r B$, $q n r S$ and qepA only. The combination of qnrA+qnrB was carried by three isolates, one isolate carried the $q n r A+q n r S$ combination and four of the isolates carried the $q n r B+q n r S$ combination. There was no carriage of a combination of $q n r A+q e p A$, while four isolates carried a combination of $q n r B+q e p A$. One of the forty-three isolates carried $q n r S+q e p A$ concurrently, while none of the isolates carried more than a combination of two PMQR genes.

\section{Discussion}

Unrestricted access to antimicrobials over the counter coupled with the unguided use of antibiotics in developing countries especially Nigeria, has contributed in no small portion to the rapid rise in antibiotic resistance. This has negatively affected the efficacy of most antibiotics in the treatment of infections, such as UTIs. Owing to the increased patronage of fluoroquinolone antibiotics since the 2000s, there has been an uncontrollable rise in the level of resistance shown to these agents in Nigeria. This has also fueled the need for bacteria to evolve several coping mechanisms to deal with the increased exposure to these antibiotics (Lamikanra et al. 2011; Chattaway et al. 2016; Ogbolu et al. 2016).

In this study, the most frequently isolated uropathogenic bacteria were from the genus Escherichia, which accounted for $42.5 \%$ (31/73) of the ciprofloxacin-resistant uropathogens. This was followed by the genus Klebsiella with 27/73 (36.9\%). Pasom et al. (2013) reported the recovery of Escherichia coli and Klebsiella spp. in samples of urinary origin obtained from a Teaching Hospital in Thailand. In their study, 49/75 (65.3\%) of Klebsiella spp. obtained were resistant to quinolone antibiotic, with 22.3\% (27/121) of the Escherichia coli isolates showing resistance to the quinolone antibiotic used in the study. The only difference between their study and this current study is that Klebsiella spp. occurred more frequently in their study as against Escherichia coli in this present study. Numerous studies have reported the predominance of Escherichia coli in samples of clinical origin, and they even went ahead to conclude that the organism accounts for a very high percentage of Urinary Tract Infections (UTIs).

A study carried out by Marei et al. (2019) on ESBLand non-ESBL- producing Enterobacteriaceae from UTI reported a percentage occurrence of $61.2 \%$ of Escherichia coli, followed by Klebsiella spp., accounting for $21.8 \%$ of the total isolates obtained. This same trend of Escherichia coli and Klebsiella spp. dominating in isolates from urinary sources was observed in this study. Other bacteria notably the members of the Enterobacterales have also been recovered from samples of UTI infected patients. In a study carried out by Ezeh et al. (2017), bacteria of the genera Salmonella, Enterobacter, Serratia, Klebsiella, Escherichia and Acinetobacter were encountered from urinary sources, with Acinetobacter being prevalent. This is in concordance with this study, where all the aforementioned genera with the exception of Serratia spp., and inclusive of Citrobacter spp. were also obtained in the urine samples of patients diagnosed with UTI infections.

The occurrence of PMQR determinants in isolates obtained from urine samples of patients diagnosed with UTI has been well documented in several countries of the world. In a study carried out in Italy by Musumeci et al. (2012), the carriage of PMQR genes by uropathogenic Escherichia coli was reported, while Deepak et al. (2009), Nazik et al. (2011), Sheikh et al. (2019), Badamchi et al. (2019), Hashemizadeh et al. (2019), Kammili et al. (2020), in their respective studies have all reported the prevalence and distribution of PMQR determinants in bacteria from urinary sources in different parts of the globe. This current study reports the occurrence of PMQR genes in bacteria obtained from urine samples of patients diagnosed with UTI and attending the University College Hospital (UCH), Ibadan, South-west Nigeria, over a period of 4 months.

The $q n r$ genes are pentapeptide proteins whose major function is the protection of the quinolone targets, topoisomerase IV and DNA gyrase. They have been reported in bacteria from different compartments including human, animal and environment (Briales et al. 2012; Chen et al. 2012). The genes which are housed on mobile genetic elements (MGE) have five major phylogenetic groups. In this present study, three qnr genes (qnrA, qnrB and $q n r S)$ were targeted in the ciprofloxacin-resistant uropathogens. Of these three genes, $q n r B$ was predominant, as it was detected in $32.9 \%$ of the isolates, followed by $q n r S(20.5 \%)$ and $q n r A$ (10.9\%). The predominance of the $q \eta r B$ among the $q n r$ genes is consistent with the study of Badamchi et al. (2019) who reported a percentage occurrence of $41.8 \%$ of the gene, making it the most 
predominant PMQR gene in their study. This is in addition to the work of Nourozi et al. (2020), who reported the detection of $q n r$ genes among Klebsiella spp. isolated from different clinical samples, including urine. The predominant quinolone resistance gene in their study was qnrB (43\%), followed by qnrS (34\%) and qnrA (23\%). Several other studies have reported the detection of $q n r-$ encoding genes in isolates of urinary origins. Notable among them were Nazik et al. (2011), Pasom et al. (2013), Hashemizadeh et al. (2019) and Salah et al. (2019).

The qur genes have also been widely reported in other isolates apart from the usual suspects, Escherichia coli and Klebsiella spp., which are the major organisms extensively worked upon by most researchers. In a study by Yang et al. (2015), the detection of plasmidmediated qnr genes was reported in Acinetobacter baumannii, with qnrB frequently occurring having been detected in $92 / 95$ (96.8\%) of the isolates obtained, while the other variants, $q n r A$ and $q n r S$, were not detected. In this present study, only one of the two ciprofloxacinresistant Acinetobacter baumannii showed the carriage of $q n r B$. Bacteria of the following genera: Enterobacter, Pseudomonas, Proteus, Salmonella and Citrobacter were also found to carry the targeted PMQR genes in this study. The isolation of Acinetobacter baumannii and Salmonella spp., showing the carriage of PMQR genes is in concordance with the work of Ezeh et al. (2017) who reported the isolation of Acinetobacter baumannii and Salmonella species showing the carriage of PMQR determinants from uropathogens isolated from the urine samples of asymptomatic female students in a University in Northern Nigeria.

Apart from the $q n r$ genes which were detected in the ciprofloxacin-resistant isolates from this study, the quinolone efflux pump (qepA) was also detected in the isolates. Until 2007, when the qepA gene was detected in a clinical Escherichia coli isolate from Japan, as a novel plasmid-mediated efflux pump, no PMQR efflux pump was in existence. The gene, which is responsible for the reduction of quinolone accumulation in bacteria cell has been widely detected in many Gram-negative genera in many Asian countries and Africa, most notably Nigeria. There is a relative low occurrence of the gene in quinolone-resistant strains, and this has been largely attributed to its limited host spectrum, as a result of its newness in comparison with other PMQR genes (Chen et al. 2007, 2012; Yamane et al. 2007; Ogbolu et al. 2011). In this study, nine of the seventy-three ciprofloxacin-resistant isolates (12.3\%) carried qepA gene, with eight of them identified as Escherichia coli and the ninth being Enterobacter cloacae. The frequency of occurrence of the gene in this study is higher than what was reported in some other studies on uropathogenic bacteria. Nazik et al. (2011) reported a frequency of $5.7 \%$ in their study carried out at two Turkish hospitals, while Badamchi et al. (2019) detected qepA in $7.3 \%$ of the isolates in their study. Pasom et al. (2013) on the other hand reported the absence of the gene in uropathogenic isolates obtained from a Teaching hospital in Thailand, same as Ehwarieme et al. (2021). In contrast however, Ezeh et al. (2017) reported the occurrence of the gene in $70 \%$ of the isolates obtained in their study, while Ogbolu et al. (2016) in their study on gramnegative bacteria from a Nigerian hospital reported $18.7 \%$ occurrence of $q e p A$. There was co-occurrence of PMQR genes in thirteen of the seventy-three ciprofloxacin-resistant bacteria in this study, and this presents a rather worrisome situation, as these genes could be transmitted to bacteria in other compartments notably the environment, which could further facilitate the proliferation of quinolone resistance.

\section{Conclusions}

Enterobacteriaceae are commonly recovered from of UTIs, however the high carriage of PMQR genes which confer resistance to first line treatment drug (quinolones) is quite alarming. This study showed that $73(60.8 \%)$ of the uropathogens obtained from the hospital showed resistance to ciprofloxacin while 43/73 (58.9\%) showed the presence of at least one PMQR genes, with qnrB being the most prevalent. There is, therefore, a need to regulate the use of quinolone drugs in UTI treatment, to clamp down on the increasing tide of resistance to these drugs.

\section{Abbreviations}

PMQR: Plasmid-Mediated Quinolone Resistance; UTI: Urinary Tract Infection; CLSI: Clinical and Laboratory Standards Institute; ARG: Antibiotic Resistance Gene; PCR: Polymerase Chain Reaction.

\section{Acknowledgements \\ The authors acknowledge the contribution of the industrial training students towards the successful execution of this study and the Department of Medi- cal Microbiology and Parasitology, UCH for granting access for collection of isolates.}

\section{Authors' contributions}

AOA conceived the study. AOA and OCA designed the study. AOA, SU, OCA and AVO carried out the laboratory work. AOA, SU, OCA, AVO and AAO wrote the first draft of the manuscript. AOA and AVO did the article formatting. AOA, $O C A$ and $A A O$ read the final version of the manuscript. All authors read and approved the final manuscript.

\section{Funding}

The study did not receive any funding.

\section{Availability of data and materials}

The datasets used and/or analysed during the current study are included in the article. 


\section{Declarations}

Ethics approval and consent to participate

Not applicable.

\section{Consent for publication}

Not applicable.

\section{Competing interests}

The authors declare that they have no competing interests.

\section{Author details}

${ }^{1}$ Environmental Microbiology and Biotechnology Laboratory, Department of Microbiology, University of Ibadan, Ibadan, Nigeria. ${ }^{2}$ Molecular Biology and Biotechnology Laboratory, Department of Microbiology, University of Ibadan, Ibadan, Nigeria. ${ }^{3}$ Pathogenic Microbiology Laboratory, Department of Microbiology, University of Ibadan, Ibadan, Nigeria. ${ }^{4}$ Department of Pharmaceutical Microbiology, Faculty of Pharmacy, University of Ibadan, Ibadan, Nigeria. ${ }^{5}$ Microbial Physiology and Biochemistry Laboratory, Department of Microbiology, University of Ibadan, Ibadan, Nigeria.

Received: 29 July 2021 Accepted: 25 January 2022

Published online: 07 February 2022

\section{References}

Ade S, Harries AD, Tre'bucq A et al (2014) National profile and treatment outcomes of patients with extrapulmonary tuberculosis in Benin. PLoS ONE 9:e95603

Aibinu I, Adenipekun E, Odugbemi T (2004) Emergence of quinolone resistance amongst Escherichia coli strains isolated from clinical infections in some Lagos state hospitals in Nigeria, Niger. J Health Biomed Sci 3:73-78

Aibinu IE, Adenipekun EO, Nwaka DC et al (2008) Emergence of crossresistance to fluoroquinolones in Gram-negative isolates from cancer infections in a tertiary hospital in Nigeria. J Am Sci 4:4

Alikhani MY, Hashemi SH, Aslani MM et al (2013) Prevalence and antibiotic resistance patterns of diarrheagenic Escherichia coli isolated from adolescents and adults in Hamadan, Western Iran, Iran. J Microbiol 5:42-47

American Urological Association (AUA) (2016). Journal of Urology

Badamchi A, Shima J, Reza F et al (2019) Molecular detection of plasmidmediated quinolone resistant genes in uropathogenic E. coli from tertiary referral hospital in Tehran, Iran. Arch Pharmacol Ther 1:1

Briales A, Rodríguez-Martínez JM, Velasco C et al (2012) Prevalence of plasmidmediated quinolone resistance determinants qnr and $a a c\left(6^{\prime}\right)-1 b-c r$ in Escherichia coli and Klebsiella pneumoniae producing extended-spectrum beta-lactamases in Spain. Int J Antimicrob Agents 39:431-434

Chattaway MA, Aaron OA, Kayode F et al (2016) Fluoroquinolone-resistant enteric bacteria in Sub-Saharan Africa: clones, implications and research needs. Front Microbiol 7:558

Chen PL, Wu CJ, Chang CM et al (2007) Extra-intestinal focal infections in adults with Salmonella enterica serotype Choleraesuis bacteraemi. J Microbiol Immunol Infect 40:240-247

Chen X, Zhang W, Pan W et al (2012) Prevalence of qnr, aac(6')-Ib-cr, gepA and oqXAB in Escherichia coli isolated from humans, animals and the environment. Antimicrob Agents Chemother 56:3423-3427

Deepak RN, Koh TH, Chan KS (2009) Plasmid-mediated quinolone resistance determinants in urinary isolates of Escherichia coli and Klebsiella pneumoniae in a large Singapore hospital. Ann Acad Med Singapore 38:1070e3

Ehwarieme DA, Whiliki OO, Ejukonemu FE (2021) Occurrence of plasmid mediated fluoroquinolone resistance genes amongst enteric bacteria isolated from human and animal sources in Delta State, Nigeria. AIMS Microbiol 7:75-95

Ezeh PA, Tende M, Bolaji RO et al (2017) Prevalence of aac(6')-Ib-Cr and qepA genes among quinolone resistant uropathogens isolated from asymptomatic female students of a northern university on Nigeria. Clin Microbiol $6: 298$

Foxman B (2014) Urinary tract infection syndromes: occurrence, recurrence, bacteriology, risk factors, and disease burden. Infect Dis Clin N Am 28:1-13
Grabe M, Bartoletti R, Bjerklund-Johansen TE et al (2015) For the European Association of Urology, guidelines on urological infections. Eur Assoc Urol 182:237-257

Gugliandolo C, Lentini V, Spano A et al (2010) Conventional and molecular methods to detect bacterial pathogens in mussels. Lett Appl Microbiol 52:15-21

Hashemizadeh Z, Samane M, Davood K et al (2019) Prevalence of plasmidmediated quinolone resistance and ESBL genes in Escherichia coli isolated from urinary tract infections and fecal samples in Southeast Iran. Gen Rep 17:100487

Hernández A, Sánchez MM, Martínez JL (2011) Quinolone Resistance: Much More than Predicted. Front Microbiol 2(22):1-6

Hooper DC, Jacoby GA (2015) Mechanisms of drug resistance: quinolone resistance. Ann N Y Acad Sci 1354(1):12-31

Jacoby GA (2005) Mechanisms of resistance to quinolones. Clin Infect Dis 41:S120-S126

Jacoby G, Cattoir V, Hooper D et al (2008) qnr gene nomenclature. Antimicrob Agents Chemother 52:92297-92299

Kammili N, Rani M, Styczynski A et al (2020) Plasmid mediated antibiotic resistance among uropathogens in primigravid women-Hyderabad, India. PLOS ONE 15:e0232710

Lamikanra A, Crowe JL, Lijek RS et al (2011) Rapid evolution of fluoroquinolone-resistant Escherichia coli in Nigeria is temporally associated with fluoroquinolones use. BMC Infect Dis 11:312

Mandell GL (2005) Mandell, Douglas, and Bennett's principles and practice of infectious diseases. Elsevier, Amsterdam

Marei YE, Omayma MA, Sahar ZE et al (2019) Detection of plasmid-mediated quinolone resistance determinants in ESBLs and non-ESBLs producing Enterobacteriaceae from Urinary Tract Infections. Ann Clin Immuno Microbiol 1:1008

Musumeci R, Marco R, Roberto G et al (2012) Prevalence of plasmid-mediated quinolone resistance genes in uropathogenic Escherichia coli isolated in a teaching hospital of northern Italy. Micro Drug Resis 18:1

Nazik H, Bayhan B, Betigül Ö et al (2011) Plasmid-mediated quinolone resistance genes in Escherichia coli urinary isolates from two teaching hospitals in Turkey: coexistence of TEM, SHV, CTX-M and VEB-1 Type-lactamases. Tropic J Pharm Res 10:325-333

Nourozi M, Shiva M, Sajad O (2020) Frequency of plasmid-mediated quinolone resistance genes qnr A, anr B and qnr S among clinical isolates of Klebsiella pneumonia. J Appl Biotechnol Rep 7:203-207

Ogbolu DO, Daini OA, Ogunledun A et al (2011) High levels of multidrug resistance in clinical isolates of gram-negative pathogens from Nigeria. Int J Antimicrob Agents 37:62-66

Ogbolu DO, Alli AO, Anorue MC et al (2016) Distribution of plasmid-mediated quinolone resistance in Gram-negative bacteria from a tertiary hospital in Nigeria. Indian J Pathol Microbiol 59:322-326

Ohene S, Sarah F, Prince DB (2019) Childhood tuberculosis and treatment outcomes in Accra: a retrospective analysis. BMC Infect Dis 19:749

Pasom W, Aroonwadee C, Aroonlug W et al (2013) Plasmid-Mediated Quinolone Resistance Genes, $a a c\left(6^{\prime}\right)-l b-c r$, $q n r S$, $q n r B$, and $q n r A$, in Urinary Isolates of Escherichia coli and Klebsiella pneumoniae at a Teaching Hospital, Thailand. Jpn J Infect Dis 66:428-432

Poirel L, Van DL, Mammeri H et al (2005) Association of plasmid-mediated quinolone resistance with extended spectrum $\beta$-lactamase VEB-1. Antimicrob Agents Chemother 49:3091-3094

Salah FD, Serge TS, Abdoul KO et al (2019) Distribution of quinolone resistance gene (qnr) in ESBL-producing Escherichia coli and Klebsiella spp. in Lomé, Togo. Antimicrob Resist Infect Cont 8:104

Shahcheraghi F, Nobari S, Rahmati Ghezelgeh F et al (2013) First report of New Delhi metallo-beta-lactamase-1-producing Klebsiella pneumoniae in Iran. Microb Drug Resist 19:30-36

Sheikh AF, Hojat V, Mojtaba S et al (2019) Frequency of quinolone resistance genes among extended-spectrum $\beta$-lactamase (ESBL)-producing Escherichia coli strains isolated from urinary tract infections. Trop Med Health 47:19

Strahilevitz J, Jacoby GA, Hooper DC et al (2009) Plasmid-mediated quinolone resistance: a multifaceted threat. Clin Microbiol Rev 22:664-689

Wu JJ, Ko WC, Tsai SH et al (2007) Prevalence of plasmid-mediated quinolone resistance determinants $q n r A$, anrB, and anrS among clinical isolates of Enterobacter cloacae in a Taiwanese hospital. Antimicrob Agents Chemother 51:1223-1227 
Yamane K, Wachino J, Suzuki S et al (2007) New plasmid mediated fluoroquinolone efflux pump, gepA, found in an Escherichia coli clinical isolate. Antimicrob Agents Chemother 5:3354-3360

Yang QE, Sun J, Li L et al (2015) IncF plasmid diversity in multi-drug resistant Escherichia coli strains from animals in China. Front Microbiol 6:964-972

\section{Publisher's Note}

Springer Nature remains neutral with regard to jurisdictional claims in published maps and institutional affiliations.

Submit your manuscript to a SpringerOpen ${ }^{\odot}$ journal and benefit from:

- Convenient online submission

- Rigorous peer review

- Open access: articles freely available online

- High visibility within the field

- Retaining the copyright to your article

Submit your next manuscript at $\boldsymbol{\nabla}$ springeropen.com 